\title{
18-Yekta Kopan’ın “Aşk Mutfağından Yalnızlık Tarifleri” adlı öykü kitabı üzerine sözlüksel alan kuramı temelinde bir inceleme
}

\section{Ceren SELVI'1}

APA: Selvi, C. (2020). Yekta Kopan’ın “Aşk Mutfağından Yalnızlık Tarifleri” adlı öykü kitabı üzerine sözlüksel alan kuramı temelinde bir inceleme RumeliDE Dil ve Edebiyat Araştırmaları Dergisi, (Ö8), 234-247. DOI: 10.29000/rumelide.824558.

\section{$\ddot{O} \mathbf{z}$}

Sözlüksel alan kavramı, bir kavram etrafında bir araya gelen ve bireylerin zihninde aynı imgenin canlanmasını sağlayan yapısal düzendir. Sözlüksel alanın tespiti için tek bir metne veya tek bir yazara/şâire odaklanmak gerekir. Bir metin içerisinde yer alan çeşitli kavramlar/motifler bir araya gelerek o metnin sahip olduğu sözlüksel alanı karşılarlar. Sözlüksel alan terimi, aynı metin içerisinde sabit kalmak şartı ile, metin çözümlemesinde çok önemli bir yere sahiptir. Bir metnin sözlüksel alanı, birçok imgenin kaynağı olabilir ve metin içerisinde yer alan motifler bir anlam alanı etrafında toplanarak metnin sözlüksel alanının tespitini kolaylaştırır.Dilde yer alan sözcükler yapısal dilbilimden itibaren gösterge olarak anılmıştır. Bu göstergeler bir araya gelerek dilin dizgesini/yapısını oluştururlar. Bir gösterge tek başına bir anlam ifade etmezken diğer göstergeler ile bir araya geldiği zaman bir anlam alanı oluştururlar. Bu oluşan anlam alanına bağlam adı verilmektedir. Sözlüksel alan ile metnin sahip olduğu bu bağlamlar ortaya çıarılmaktadır. Bir metin içerisinde sözlüksel alan oluşturan terimlerin tespiti; metin oluşturan yazarın imge dünyasını ortaya koyması bakımından oldukça önemlidir. Bu çalışmada da sözlüksel alan hakkında yapılan çalışmalar hakkında bilgi verilecek ve Yekta Kopan'ın “Aşk Mutfağından Yalnızlık Tarifleri” adlı öykü kitabı içerisinde yer alan Aşk Mutfağından Yalnızhk Tarifleri, Düş Eş, Rakı, Su ve Buz, Maskeli Süvari, Oyun Evi, Elma Ağacındaki Cadı, Çıkış Noktası, Mevsim Normalleri, Köprüden Görünüş ve Yayınlanmamış Bir Söyleşi adlı öyküler üzerinde sözlüksel alan sınıflandırması yapılacaktır. Her bir öykünün temel çıkış noktasını oluşturan motifler tespit edilecek, bu motiflerin oluşturduğu sözlüksel alan kavramı açıklanacak ve kısaca öykünün teması ele alınacaktır. Yapılan bu çözümleme ile yazarın dünyaya bakış açısı, imge dünyası ve okuyucuya iletmek istediği mesajlar dilbilim alanının bakış açısı ile ortaya konmaya çalışılacaktır.

Anahtar kelimeler: Dilbilim, sözlüksel alan, aağlam, Yekta Kopan

\section{An investigation on the story book of Yekta Kopan "Recipes For a Loneliness From The Cuisine of Love" on the basis of the lexical field theory ${ }^{2}$}

\begin{abstract}
The lexical field concept is the structural order that comes together around a concept and enables the same image to be revived in the minds of individuals. To determine the lexical field, it is necessary to focus on a single text or a single author / poet. Various concepts / motifs in a text come together to meet the lexical field of that text. The lexical field term has a very important place in text analysis, provided that it remains constant within the same text. The lexical area of a text can be the
\end{abstract}

Dr. Arş. Gör., Ankara Yıldırım Beyazıt Üniversitesi, İnsan ve Toplum Bilimleri Fakültesi, Türk Dili ve Edebiyatı Bölümü (Ankara, Türkiye), ceren.ybu@gmail.com ORCID ID: 0000-0002-7606-4292 [Makale kaylt tarihi: 12.09.2020-kabul tarihi: 20.11.2020; DOI: 10.29000/rumelide.824558]

Bu çalışma 04.09.2020 tarihinde düzenlenen II. Uluslararası Filoloji Kongresi'nde sunulan bildiriden uyarlanmıştır. 
source of many images, and the motifs in the text are gathered around a meaning area, making it easier to identify the lexical area of the text. The words in the language have been referred to as indicators since structural linguistics. These signs come together to form the string / structure of the language. While an indicator alone does not make sense, when it comes together with other indicators, they form an area of meaning. This field of meaning is called context. With the lexical field, these contexts of the text are revealed. In this study, information about the studies on the lexical field will be given and Yekta Kopan's recipes of Loneliness from Love Cuisine, Dream Spouse, Rakı, Water and Ice, Masked Horseman, Playhouse, Apple Tree A lexical area classification will be made on the stories named Witch, Origin Point, Seasonal Normals, View from the Bridge and An Unpublished Interview. The motifs that constitute the basic starting point of each story will be determined, the lexical field concept created by these motifs will be explained and the theme of the story will be briefly discussed. With this analysis, the author's point of view to the world, the world of images and the messages he wants to convey to the reader will be tried to be revealed with the perspective of the field of linguistics.

Keywords: Linguistics, lexical field, context, Yekta Kopan

\section{Giriş}

Sözlüksel alan kavramı, bir kavram etrafında bir araya gelen ve bireylerin zihninde aynı imgenin canlanmasını sağlayan yapısal düzendir. Sözlüksel alanın tespiti için tek bir metne veya tek bir yazara/şâire odaklanmak gerekir. Bir metin içerisinde yer alan çeşitli kavramlar/motifler bir araya gelerek o metnin sahip olduğu sözlüksel alanı karşılarlar. Sözlüksel alan terimi, aynı metin içerisinde sabit kalmak şartı ile, metin çözümlemesinde çok önemli bir yere sahiptir. Bir metnin sözlüksel alanı, birçok imgenin kaynağı olabilir ve metin içerisinde yer alan motifler bir anlam alanı etrafında toplanarak metnin sözlüksel alanının tespitini kolaylaştırır.

Dilde yer alan sözcükler yapısal dilbilimden itibaren gösterge olarak anılmıştır. Bu göstergeler bir araya gelerek dilin dizgesini/yapısını oluştururlar. Bir gösterge tek başına bir anlam ifade etmezken diğer göstergeler ile bir araya geldiği zaman bir anlam alanı oluştururlar. Bu oluşan anlam alanına bağlam adı verilmektedir. Sözlüksel alan ile metnin sahip olduğu bu bağlamlar ortaya çıkarılmaktadır.

İmer, Kocaman ve Özsoy, Dilbilim Sözlüğü’nde sözcük alanı kavramı ile karşılamıştır ve "Bir dilin sözvarlığında anlam açısından birbiriyle bağıntılı sözcüklerin kümeler oluşturarak içinde yer aldıkları varsayılan alan. Anlam alanları içinde renk, akrabalık, yiyecek vb. sözcük kümeleri en çok incelenen sözcük alanlarıdır. Bir sözcük alanındaki sözcüklerin anlamları birbirleriyle ilişkileri sonucu ortaya çıkar.” şeklinde tanımlar (İmer, 2013: 234). Günay Karaağaç, Dil Bilimi Terimleri Sözlüğü'nde sözlük alanı ile karşıladığı terimi, "Komşu bilgilerin adları belirli bir anlam alanı oluştururlar ve buna sözlük alanı denir.” demiş̧tir. Berke Vardar ise Açıklamalı Dilbilim Terimleri Sözlüğü’nde sözlüksel alan kavramını "Aynı gerçeklik düzlemini belirten sözlüksel birimlerin oluşturduğu yapısal düzen. Sözlüksel alan kavramı, yapısal dilbilimin bir ürünüdür ve dilin öbür kesimlerinde olduğu gibi sözlüksel boyutunda da rasgele bir sıralanış yerine, çeşitli gerçek kesimleriyle ilgili olarak bağıntısal bir düzenleniş bulunduğu varsayımına dayanır. Son yıllarda, değer kavramına öncelik tanıyan dilbilimciler A. Martinet’in değerbiliminden esinlenerek sözlükseldeğersel alandan söz etmeye başlamışlardır. Sözlüksel alan terimini kavramsal ya da anlamsal alan terimiyle özdeş biçimde kullananlar da vardır.” Şeklinde açıklar (Vardar, 2002: 185).

Sözlüksel Alan terimi, en temel tanımı ile aynı kavram etrafında bir araya gelen sözcüklerin oluşturduğu yapısal düzendir. Sözcükler tek başlarına bir anlam taşımazlar. Bir sözcenin içerisinde yer alırlarsa anlam kazanırlar. Sözce içerisinde bir araya gelip yeni bir anlam ağı oluştururlar. Başka bir deyişle, aynı kavramı sunmak ya da geliştirmek, gerçekliğin aynı alanını betimlemek, aynı düşünceyi ifade etmek için kullanılan sözcüklerin tümünün oluşturduğu yapısal düzene verilen 
Yekta Kopan’ın “Aşk Mutfağından Yalnızlık Tarifleri” adlı öykü kitabı üzerine sözlüksel alan kuramı temelinde bir inceleme / C. Selvi (pp. 234-247)

addır (Kıran, 2013: 301). Sözlüksel alan terimi, metnin dışına çıkmama koşuluyla -, metin çözümlemesinde çok üretici olabilir. (Kıran, 2013: 301).

Bir metinde aynı gerçeklik alanına ya da aynı fikre işaret eden sözcükler kümesidir. Sözlüksel alan/Kavram alanı bir dilin söz varlığında yer alan, dilin sözlüğüne girmiș bütün sözcükler ile bu sözcüklerin kazandığı yan ve mecaz bütün anlamlar ve bu sözcüklerin bir araya gelerek oluşturdukları bütün eşdizimlilikler için geçerlidir (Yılmaz-Efe, 2019: 26).

ÇIÇEK sözcüğünün sözlüksel alanlarına şu örnekler verilebilir:

Aşk, sevgi, mutluluk

Çiçekçi dükkânı

Çiçekçi

Gül, papatya, orkide

Kırmızı, beyaz, sarı vb.

Kısa bir metinde, bir şiir ya da romandan alınmış bir parçada sözlüksel alanlar incelenebilir. Ancak bir romanda, bazı sözlüksel alanların yinelenmesi, "motif" adı verilen anlam koşutlukları ve yankılanmaları yaratır (Kıran, 2013: 303).

Motifler, metin içerisinde geçen anlam ağları olarak da adlandırılabilir. Eserde yer alan bu motifler, eser üzerinden yazarın düşünce dünyasını, zihnindeki imgeleri ve okuyucuya iletmek istediği mesajları ortaya çıarır ve bunu yaparken de bir araya gelip metnin temelinde yer alan sözlüksel alanı oluştururlar. Motiflerin temel özelliği metin içerisinde tekrar etmeleridir. Bir araya gelen ve anlam olarak aynı ya da benzer kavramları oluşturan temel motifler metni anlamadaki en önemli ögelerdir.

Bir metin içerisinde sözlüksel alan oluşturan terimlerin tespiti; metin oluşturan yazarın imge dünyasını ortaya koyması bakımından oldukça önemlidir. Bu çalışmada da sözlüksel alan hakkında yapılan çalışmalar hakkında bilgi verilecek ve Yekta Kopan'ın “Aşk Mutfağından Yalnızlık Tarifleri” adlı öykü kitabı içerisinde yer alan Aşk Mutfağından Yalnızlı Tarifleri, Düş Eş, Rakı, Su ve Buz, Maskeli Süvari, Oyun Evi, Elma Ă̆acındaki Cadı, Çıkış Noktası, Mevsim Normalleri, Köprüden Görünüş ve Yayınlanmamış Bir Söyleşi adlı öyküler üzerinde sözlüksel alan sinıflandırması yapılacaktır. Her bir öykünün temel çıkış noktasını oluşturan motifler tespit edilecek, bu motiflerin oluşturduğu sözlüksel alan kavramı açıklanacak ve kısaca öykünün teması ele alınacaktır. Yapılan bu çözümleme ile yazarın dünyaya bakış açısı, imge dünyası ve okuyucuya iletmek istediği mesajlar dilbilim alanının bakış açısı ile ortaya konmaya çalışılacaktır.

\section{Inceleme}

\section{1. Öykü: Aşk Mutfağından Yalnızlık Tarifleri}

Bu öyküde anlatıcı bir reklam ajansında metin yazarı olarak çalışmaktadır. Bir gün iş yerine gelen ve işe yeni başlayan Figen'e âşı olur. Öykünün devamında Figen ile yaşadıklarını dile getirir. Anlatıcı yazma yeteneği ile günlük hayatını çok fazla özdeşleştirmiştir. Öyle ki, hayatı sanki bir öykünün içindeymişçesine yürümektedir. Sevdiği kadın Figen bir gün kendisini terk eder ve sebep olarak da hayatın gerçekleri ile değil bir öykü içinde gibi yaşamaktan mutsuz olmasını gösterir. Ancak anlatıcı sevdiği kadını kaybetmesine rağmen bu yönünü değiştirmez. Ayrılık sonrası bir gün havaalanında karşılaşırlar ve Figen kendisine yazmaya devam etmesini söyler. Anlatıı ise halen Figen’i sevmektedir ve eski hayatını özlemektedir. Anlatıının ruh hâline bireyin içsel yalnızlı̆̆ı, geçmişe olan özlem ve pişmanlıkları hâkimdir.

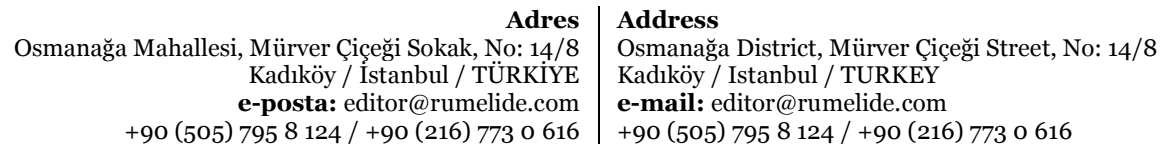


Öyküde yer alan «anılar-geçmişe özlem-aşk-aşk acısı-yalnızhk-pişmanhk» motifleri ile ele alınan sözlüksel alan «sevgi ve anılara özlem»dir.

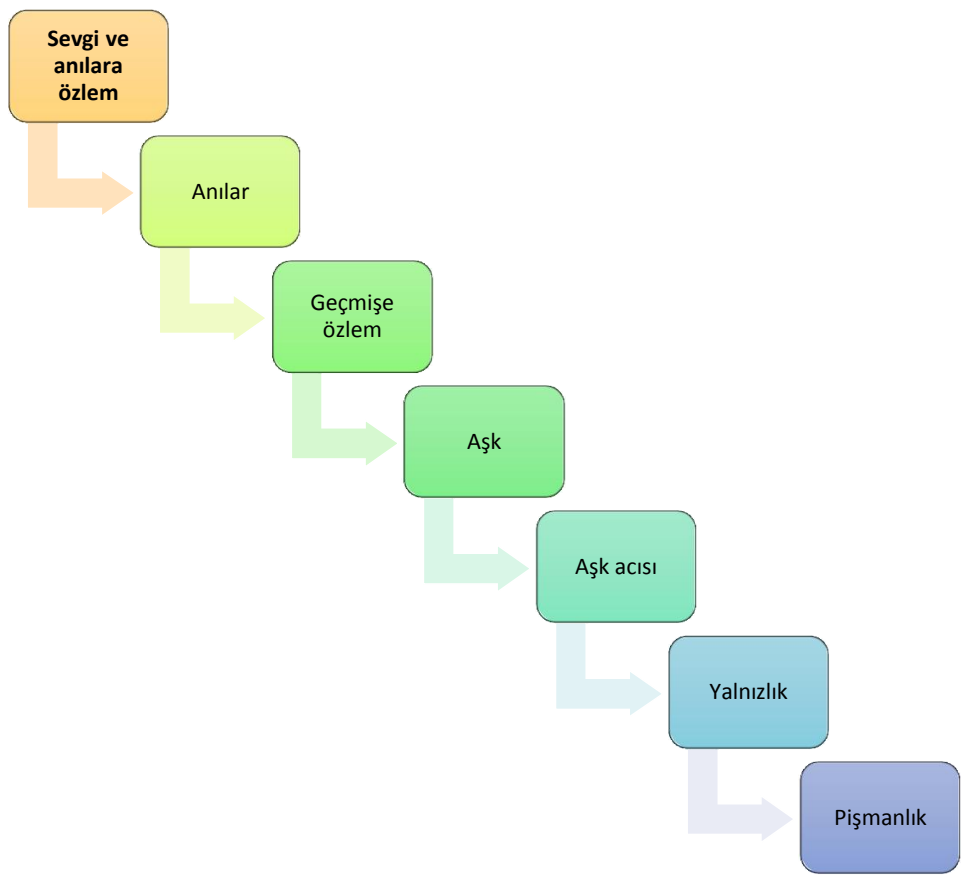

Şekil 1: Aşk Mutfağından Yalnızlık Tarifleri öyküsünün sözlüksel alanları ve motifleri

\section{2. Öykü: Düş Eş}

Bu öyküde anlatıcı babası ile olan ilişkisinden ve aralarında hiçbir zaman bir baba-oğul ilişkisinin temelinde yer alması gereken sevginin olmamasından bahseder. Babası her zaman kendisine öfke ile davranmıştır. Anlatıcı ise ömrü boyunca baba sevgisinin peşinden koşmuştur ancak akıp giden zaman hiçbir pişmanlığın düzelmesine yardımcı olmamaktadır. Öyküde, babasının ölümünden sonra onunla geçirdiği son anısını anlatır. Zihninin derinliklerinde hep sevgiye özlem vardır. Anlatıcının ruh hâline bireyin içsel yalnızlı̆̆ı ve pişmanlıkları hâkimdir.

Öyküde yer alan «baba-oğul-sevgi-geçmişe dönüş-anılar-yaşhlık-huysuzluk» motifleri ile ele alınan sözlüksel alan «sevgi ve anılara özlem»dir. 
Yekta Kopan’ın “Aşk Mutfağından Yalnızlık Tarifleri” adlı öykü kitabı üzerine sözlüksel alan kuramı temelinde bir inceleme / C. Selvi (pp. 234-247)

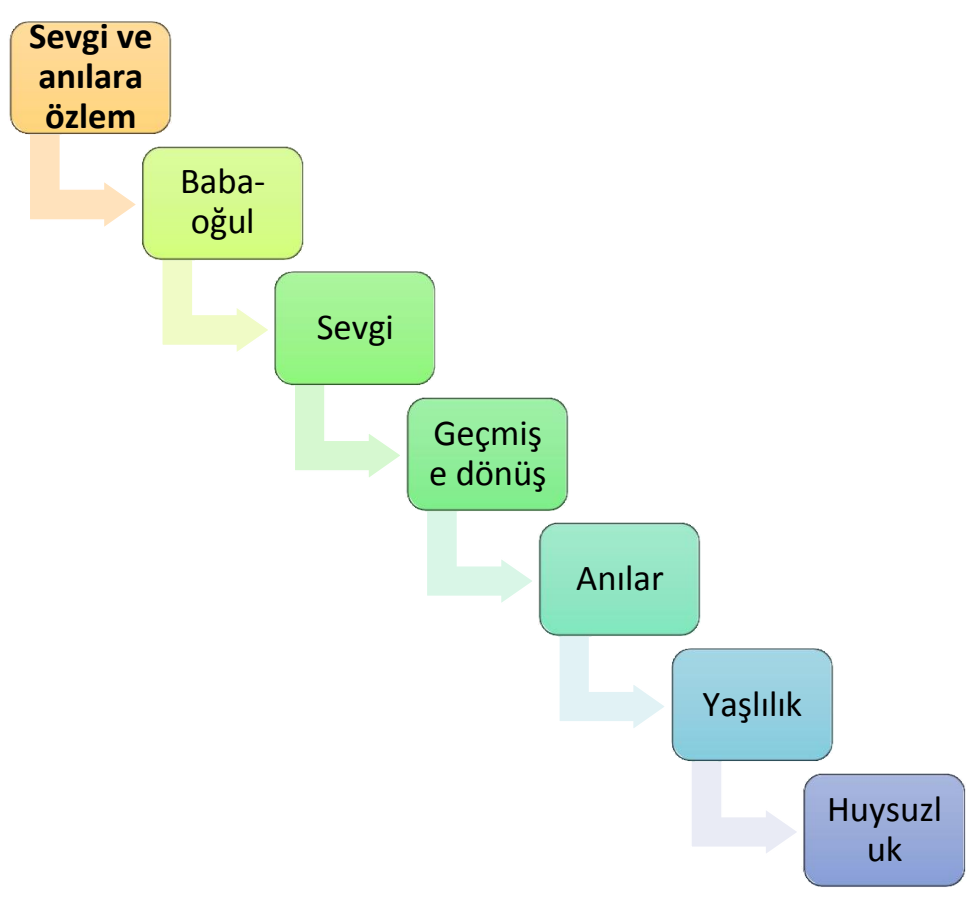

Şekil 2: Düş Eş öyküsünün sözlüksel alanları ve motifleri

3. Öykü: Rakı, Su ve Buz

$\mathrm{Bu}$ öyküde anlatıcı tiyatro sanatçısı olma hayallerini ailesinin isteği üzerine erteleyen ve her zaman tiyatroya olan özlemini yüreğinde hisseden bir adamın öyküsüdür. Öyküye günlük rutinlerini anlatarak başlar. Evde yaptığı rutinlerin ardından işe giderken yaşadığı rutinler başlar. Kendisi bir gazetecidir. Öyküyü anlattı̆̆ı gün işten kovulduğu gündür. İşten ayrıldıktan sonra çaresiz bir şekilde evine döner ve ne yapacağını düşünürken masa başına geçer ve yazmaya başlar. "Kahkaha Satan Adam” adlı yazısına başlar. Bu öykü gazeteci olduğu dönemde görüştüğü bir adamın öyküsüdür. Kendisi ile röportaj yaptığı zaman elde ettiği bilgileri artık gazetede çalışmadığı için daha tarafsız ve daha ayrıntılı bir şekilde aktarmaya karar verir. Yazdığı öykünün sahibi Fahrettin Serimoğlu adlı bir adamındır. Bu adam ailesinin isteği üzerine tiyatro sevdasını bir kenara bırakmıştır. Ancak hiçbir zaman içindeki tiyatro sevdasını öldürmemiştir. Anlatıcının ruh hâline bireyin toplum içerisinde yaşadığı ve kendisine acı veren içsel yalnızlı̆̆ı hâkimdir.

Öyküde yer alan «anılar-geçmişe dönüş-hayaller-tiyatro sevdası-aile ilişkileri-acı çekmek-mutsuzluk» motifleri ile ele alınan sözlüksel alan «sevgi ve anılara özlem»dir. 


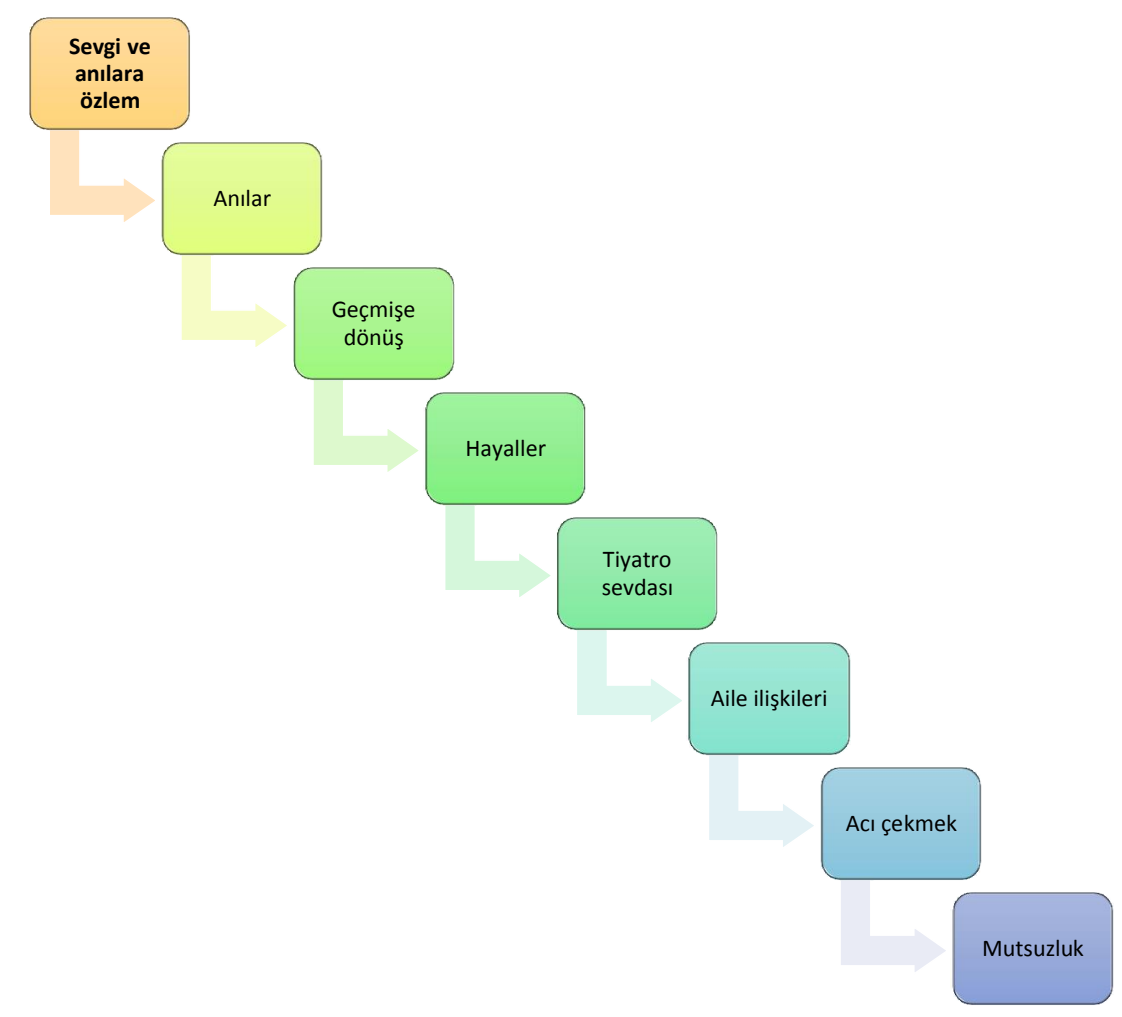

Şekil 3: Rakı, Su ve Buz öyküsünün sözlüksel alanları ve motifleri

\section{4. Öykü: Maskeli Süvari}

Bu öyküde anlatıcı babasından daha çok sevdiği amcası ile olan anılarını ve onun ölümünden sonra yaşadıklarını anlatır. Anlatıcı, hiçbir zaman babası ile yakın bir ilişki kuramamıştır. Buna rağmen amcası ile her zaman bir baba-oğul ilişkisi olmuştur. Zihninde her zaman neden babası ile değil de amcası ile bu kadar yakın olduğunu sorgularken amcasının ölümünden sonra onun dolabında bulduğu bir zarfta kendisinin aslında evlatlık olduğunu öğrenir ve zihninde yaşanan her şeyin nedeni yerine oturur. Anlatıcının ruh hâline bireyin içsel yalnızlığı ve hayat ile ilgili anlam veremediği duygular hâkimdir.

Öyküde yer alan «ölüm-aile-sevgi-yalnızhk-anılar-mektup-strlar-yalan» sözcüksel alanları ile ele alınan temel nokta «kader»dir. 
Yekta Kopan’ın “Aşk Mutfağından Yalnızlık Tarifleri” adlı öykü kitabı üzerine sözlüksel alan kuramı temelinde bir inceleme / C. Selvi (pp. 234-247)

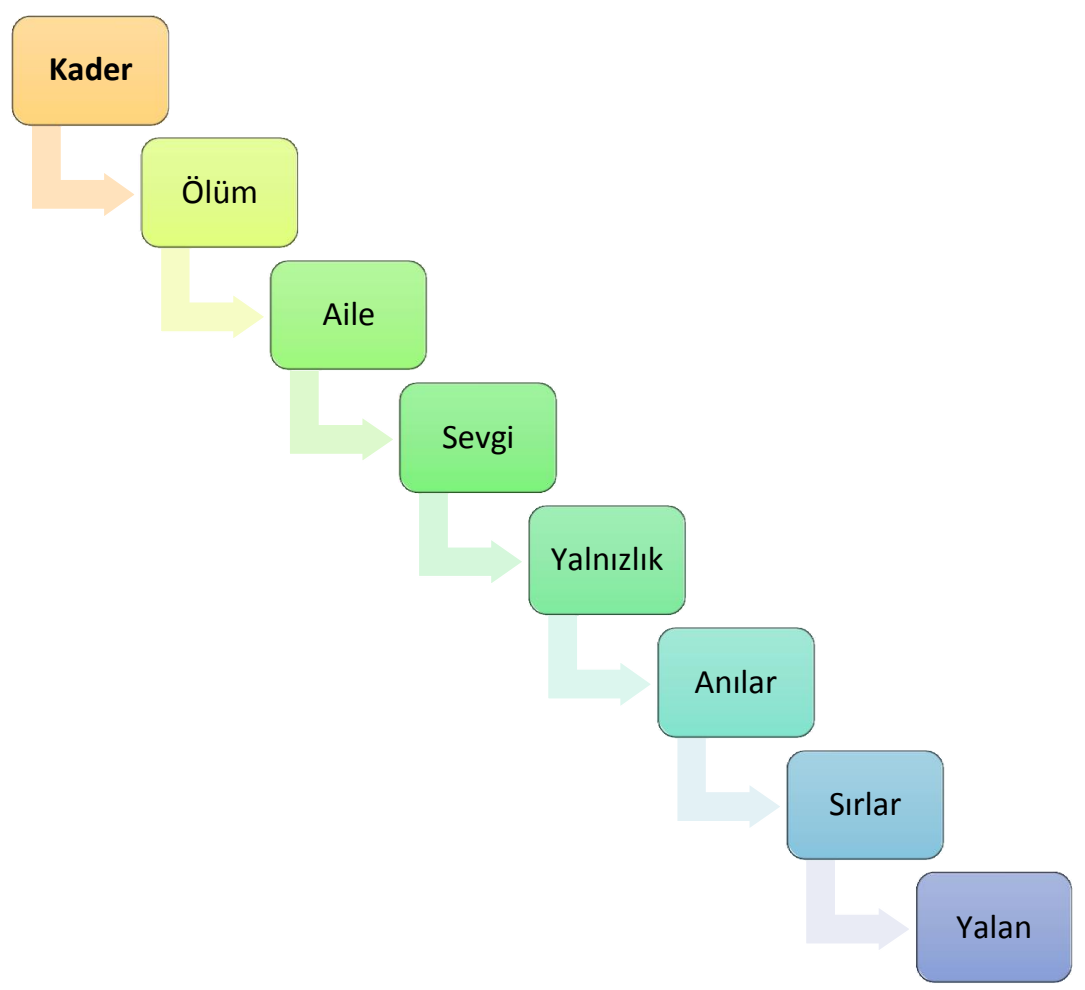

Şekil 4: Maskeli Süvari öyküsünün sözlüksel alanları ve motifleri

\section{5. Öykü: Oyun Evi}

$\mathrm{Bu}$ öyküde anlatıcı iş yerinden sevdiği kadın aracılığı ile tanıştı̆̆ı bir adamın hikâyesine yer verir. Anlatıcı insanlara güvenmeyen bir bireydir. Tanıştığı adam ise eşini ve çocuğunu kaybettikten sonra evini, çocukluğunu yaşayamamış ve oyun oynamayı özleyen yetişkinler için bir oyun evine çevirmiştir. Anlatıcı ise bunu garip bulmakta ve bu işin altından bir şey çıkacağına inanmaktadır ancak oyun evinin amacı sadece yetişkinlerin kendilerini mutlu hissetmelerini sağlamaktır. Anlatıcının ruh hâline içsel yalnızlık sebebi ile insanlara karşı hissedilen güven duygusu eksikliği hâkimdir.

Öyküde yer alan «aşk-çocukluk-insana güven-geçmişe ve çocukluğa özlem» sözcüksel alanları ile ele alınan temel nokta «güven duygusu»dur. 


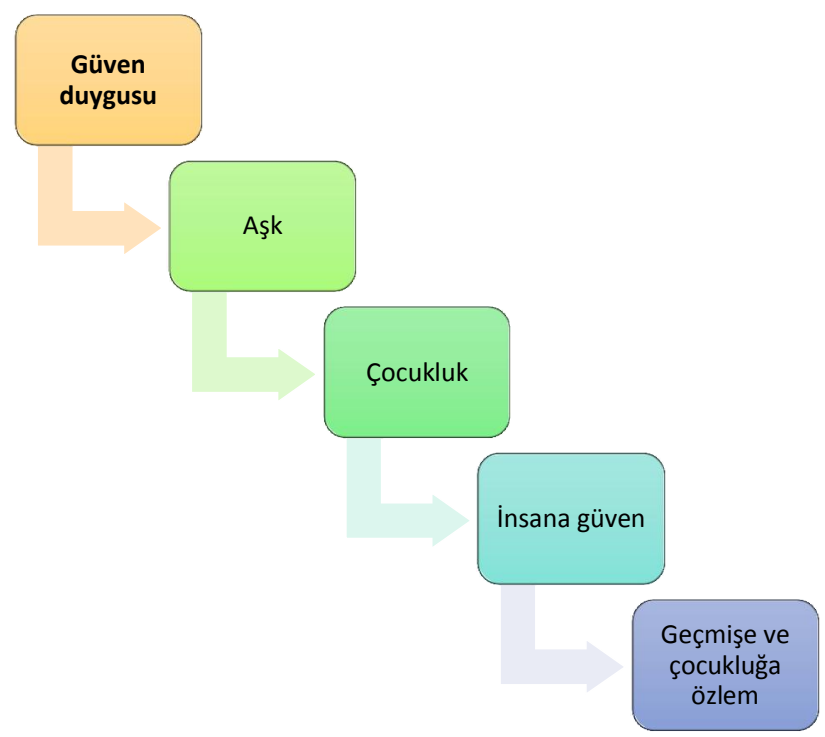

Şekil 5: Oyun Evi öyküsünün sözlüksel alanları ve motifleri

\section{6. Öykü: Elma Ağacındaki Cadı}

Bu öyküde anlatıcı üniversite arkadaşlıklarını ve bugün yaşadıkları hayatları anlatır. Sevdiği kadına kavuşamaması ancak onunla her zaman görüşmesi kendisine acı vermektedir. Arkadaş gruplarından bir kişi yazar olarak karşımıza çıkar. Kitap hepsinin eline ulaştığında aslında kendi hayatlarının yazıldığını görürler. Kitap içerisinde yer alan öyküleri okudukları zaman tüm geçmiş gözlerinin önüne dökülür ve anlatıcı sevdiği kadın olan Zümrüt ile tüm yaşadıkları ve pişmanlıkları ile yüzleşir. Anlatıcının ruh hâline bireyin geçmiş hayatı ile ilgili pişmanlıkları hâkimdir.

Öyküde yer alan «aşk-dostluk-geçmişe özlem-pişmanhk» sözcüksel alanları ile ele alınan temel nokta «geçmiş ve gelecek arasında kurulan köprü»dür. 
Yekta Kopan’ın “Aşk Mutfağından Yalnızlık Tarifleri” adlı öykü kitabı üzerine sözlüksel alan kuramı temelinde bir inceleme / C. Selvi (pp. 234-247)

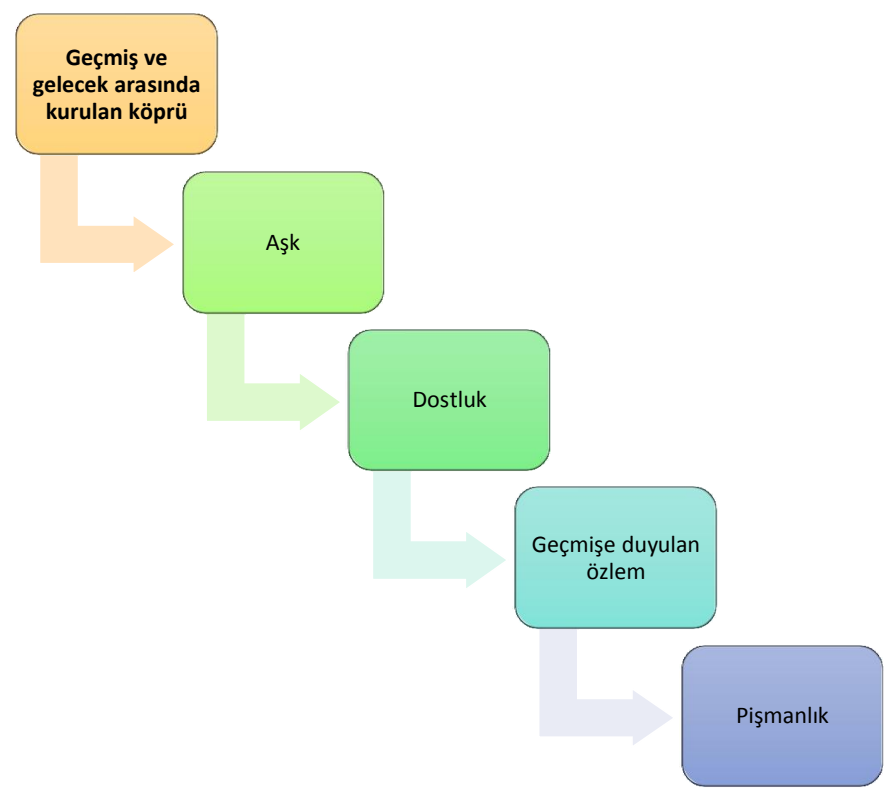

Şekil 6: Elma Ağacındaki Cadı öyküsünün sözlüksel alanları ve motifleri

\section{7. Öykü: Çıkış Noktası}

Bu öyküde anlatıcı deprem sonucunda eşini kaybetmesini ve geçmişi ile ilgili pişmanlıklarını dile getirir. Bir akşam odasında iken deprem olur ve eşinin çı̆̆llğı ile ne olduğunu anlar ve sonrasında kendini bir karanlıkta bulur. Bu esnada geçmiş tüm anıları zihninde canlanır ve bunları anlatmaya başlar. Birden ileride bir ışık görür ve o ışığa doğru ilerlerken eşi ile daha çok vakit geçirmek vb. pişmanlıklarını dile getirir. Işığa ulaşmışken aynı zamanda eşinin cansız bedenine dokunur. Öykü bu noktada çok vurucu bir üslup ile son bulmaktadır. Anlatıcının ruh hâline bireyin içsel yalnızlığı ve geçmişi ile ilgili pişmanlıkları hâkimdir.

Öyküde yer alan «deprem-acı-anılar-pişmanlık-kayıp» sözcüksel alanları ile ele alınan temel nokta «pişmanlsk ve bugün»dür. 


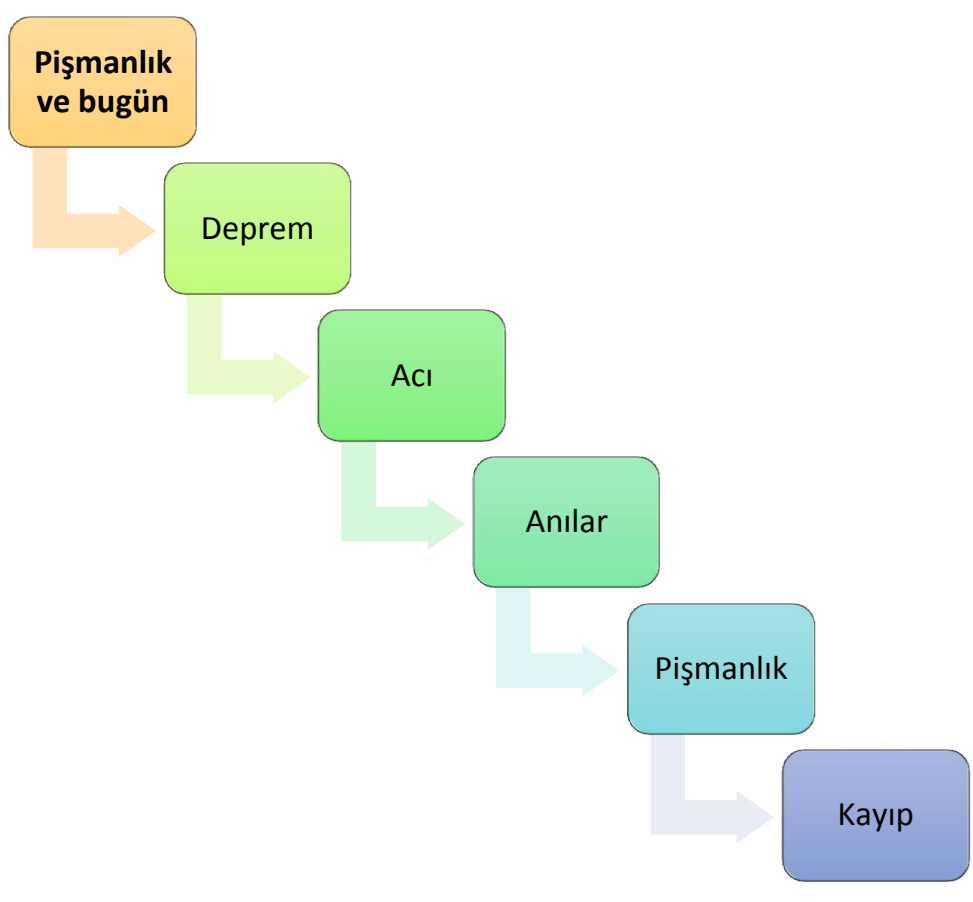

Şekil 7: Çıkış Noktası öyküsünün sözlüksel alanları ve motifleri

\section{8. Öykü: Mevsim Normalleri}

Bu öyküde anlatıcı bir televizyon kanalında muhabir olarak çalışmaktadır. Bir kameraman ve muhabir arkadaşlarının geçirdiği kaza üzerinden yalan ve kaderin birleşmesini ele alır. Bir köyde yaşayan insanların dikkat çekmek için yalan bir haber çıkarması üzerine kameraman Hüseyin ve Muhabir Akın köye giderler, röportajlarını gerçekleştirirler. Dönüş yolunda ise büyük bir kaza geçirirler. Akın’un durumu ağırdır. Anlatıcı çok sevdiği arkadaşının bu durumu nedeni ile köy halkını suçlamakta ve olayların gelişimini kendi dilinden anlatmaktadır. Anlatıcının ruh hâline özlem ve kızgınlık hâkimdir.

Öyküde yer alan «dost-yalan-kader-özlem-kzzgınlık» sözcüksel alanları ile ele alınan temel nokta «yalan ve kader»dir. 
Yekta Kopan’ın “Aşk Mutfağından Yalnızlık Tarifleri” adlı öykü kitabı üzerine sözlüksel alan kuramı temelinde bir inceleme / C. Selvi (pp. 234-247)

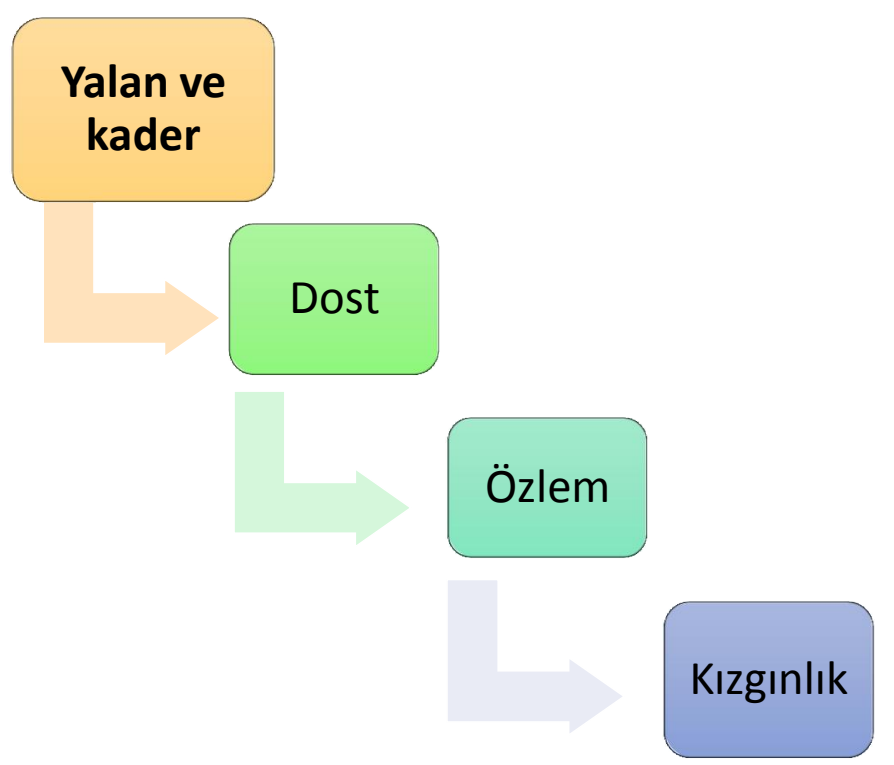

Şekil 8: Mevsim Normalleri öyküsünün sözlüksel alanları ve motifleri

9. Öykü: Köprüden Görünüş

$\mathrm{Bu}$ öyküde anlatıcı kendi içerisinde yaşadığı bir iç çatışmayı ve dostu ile arasına giren mesafeyi anlatmaktadır. Memleketini terk edip İstanbul'a yerleşir. Bu terk edişten sonra çocukluk arkadaşını olan özlemi dinmez ve birbirlerine çocukluk vakitlerinde söz verdikleri gibi mektup yazmaya başlar. Bu mektupta geçmişi anlatır, pişmanlıklarını dile getirir ve ona olan özlemini anlatır. Anlatıcının ruh hâline bireyin içsel yalnızlığı ve pişmanlıkları hâkimdir.

Öyküde yer alan «başar isteği-geçmişe özlem-yenilgiye ahssma-dost» sözcüksel alanları ile ele alınan temel nokta «geçmiş ve gelecek arasında kurulan köprü»dür. 


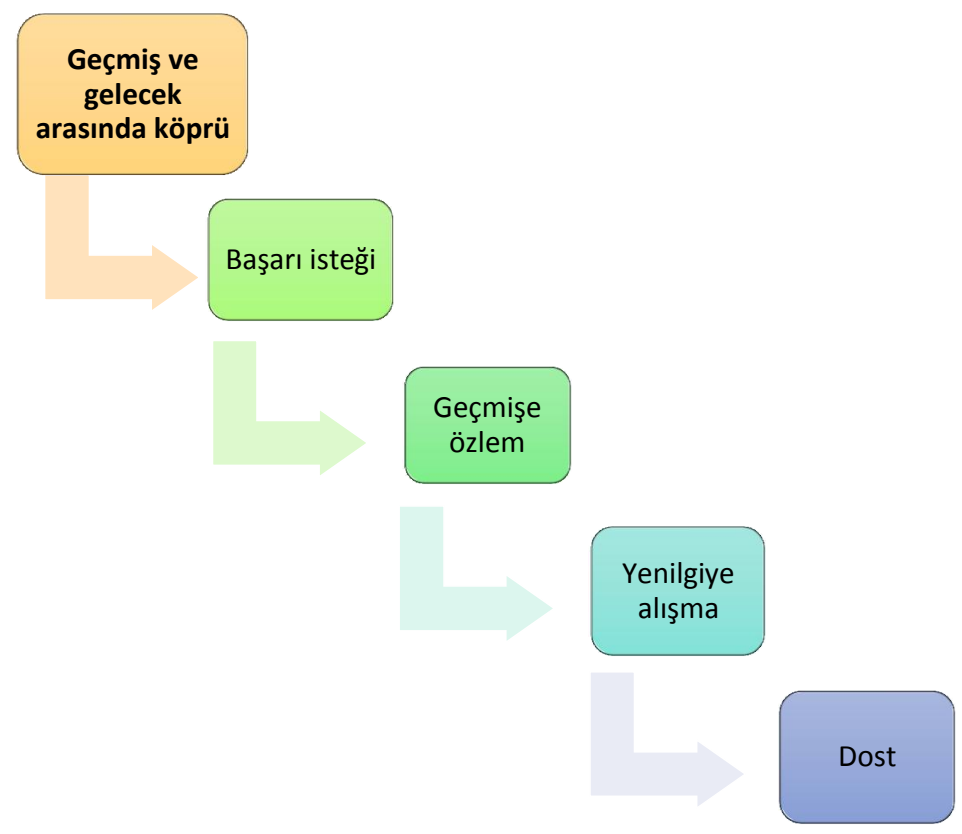

Şekil 9: Köprüden Görünüş öyküsünün sözlüksel alanları ve motifleri

10. Öykü: Yayınlanmamış Bir Söyleşi

$\mathrm{Bu}$ öyküde anlatıcı bir yazar olarak karşımıza çıkmaktadır. Başarılı ve sevilen bir öykü yazarı, eserlerinin yazılış öyküsünü röportaj esnasında anlatır. Öykülerini uyurken yazdığı ve bunun farkında olmadığı itirafını yapar. Bu durumu öncelikle anlayamadığını ve hatta korktuğunu dile getirir. Ancak daha sonra doktor yardımı ile «uyuryazan» olduğunu anlamıştır. Ancak bir gün uyku problemi başladığında bu yeteneğini kaybeder. Anlatıcının ruh hâline şaşkınlık ve yeteneğine olan hayranlığı hâkimdir.

Öyküde yer alan «düş-yetenek-geçmişe dönüş-anılar» sözcüksel alanları ile ele alınan temel nokta «yalnızhk ve yeteneğe veda»dır. 


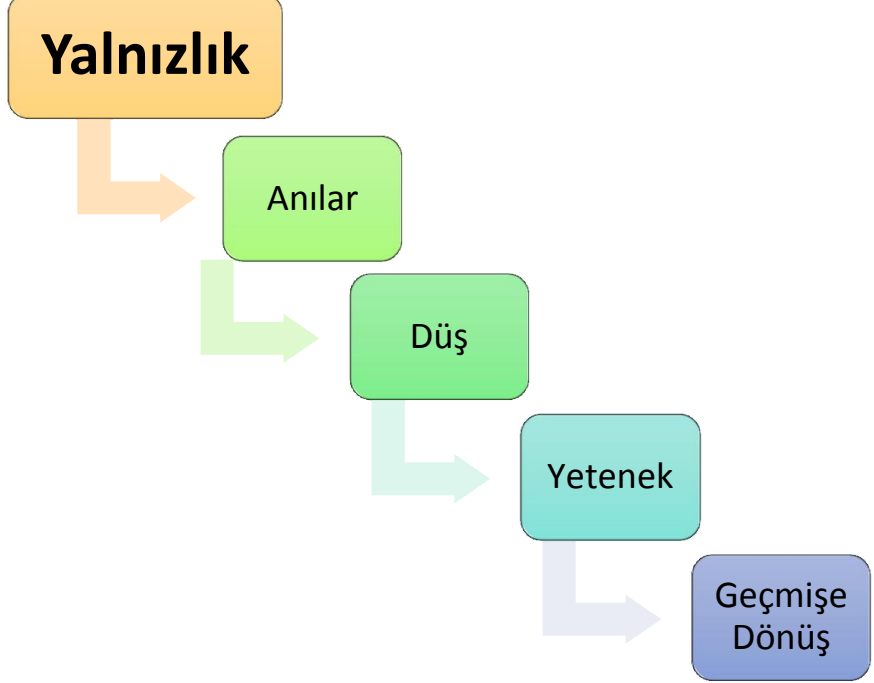

Şekil 10: Yayınlanmamış Bir Söyleşi öyküsünün sözlüksel alanları ve motifleri

\section{Sonuç}

Bir yazarın metinde vermek istediği mesaj ve bu mesajı ortaya çıkaran motiflerin bir araya gelerek oluşturduğu anlam ağı sözlüksel alan kavramı ile karşılanmaktadır. Metnin ne demek istediği, yazarın ele aldığı imgeler, metin içerisinde ele alınan motiflerin bir araya gelerek oluşturdukları sözlüksel alanı doğru anlamak öykü, şiir ya da romanın okuyucuya vermek istediklerini doğru çözümlemek açısından oldukça önemlidir.

Yekta Kopan öykülerinde anlatımı genel olarak ana karakterin iç sesi ile vermektedir. İç sesini kullanan anlatıcı/ana karakter yaşadıklarını dile getirirken okyucuda da her şeyin yaşanmışlık hissini mutlaka bırakmaktadır. Sözlüksel alan tespiti açısından güçlü bir temele oturan Yekta Kopan öykülerinde yer alan motifleri incelediğimiz bu çalışmada, öykülerinde çok çeşitli konuları işlemesine rağmen öykülerinde tespit ettiğimiz ortak sözlüksel alanlar «bireyin içsel yalnzzh̆̆g, geçmiş ve bugün arasındaki köprü ve öyküde yer alan karakterlerin anlam ile ilgili yaşadıkları pişmanlıklar» olarak karşımıza çlkmaktadır.

Şekil 11: İncelenen 10 öykünün sözlüksel alanları

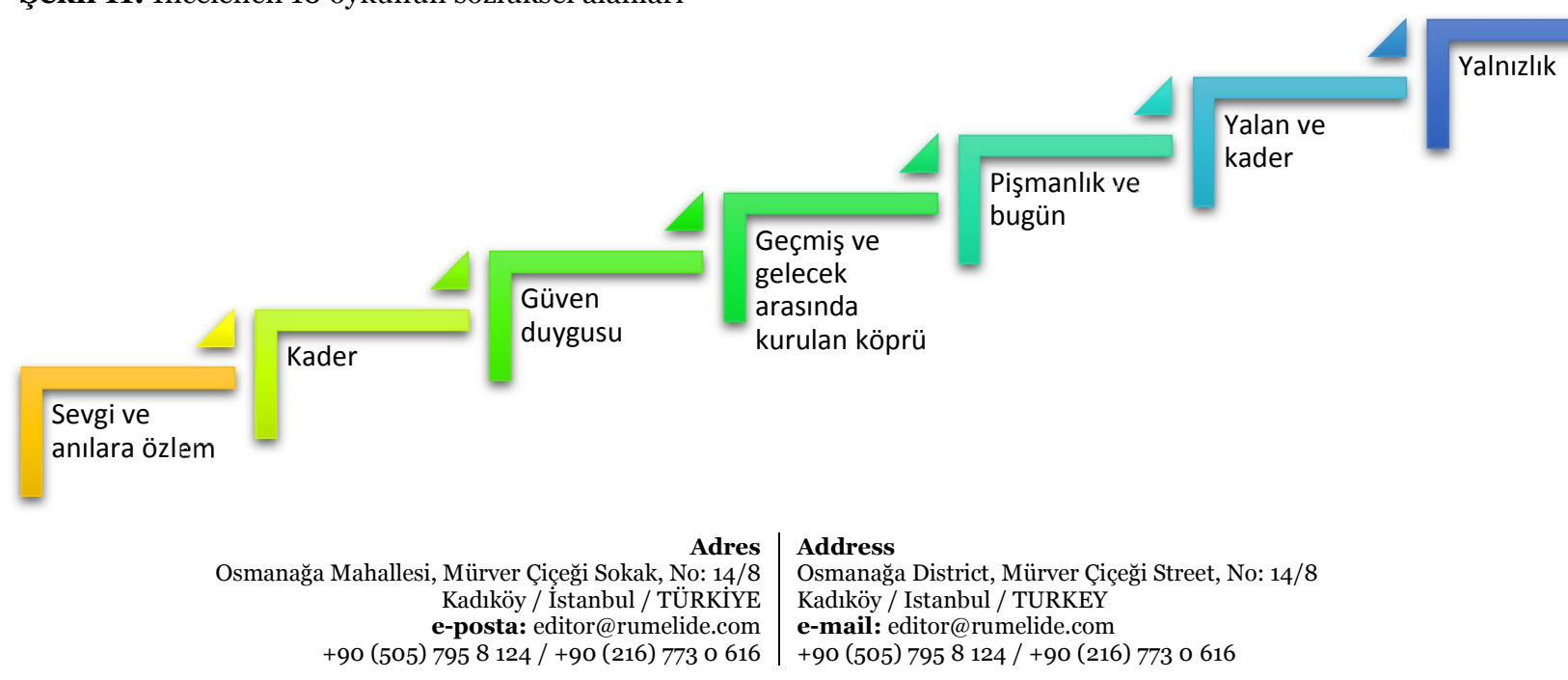




\section{Kaynakça}

Aksan, D. (2016). Anlambilim. Ankara: Bilgi1.

Alptekin, A. B. (2007). Âşık Veysel Türküz Türkü çağırırız. Ankara: Akçağ.

Günay, D. (2007). Sözcükbilime Giriş. İstanbul: Multilingual.

Huber, E. (2013). Dilbilime Giriş. İstanbul: Yabancıdil.

İmer, K.-Kocaman, A.-Özsoy, S. (2013). Dilbilim Sözlüğ̈̈. İstanbul: Boğaziçi Üniversitesi.

Karaağaç, G. (2013). Anlam (Anlam Bilimi ve İletişim). İstanbul: Kesit.

Karaağaç, G. (2013). Dil Bilimi Terimleri Sözlüğü. Ankara: TDK.

Kıran, Z.- Kıran, Eziler A. (2013). Dilbilime giriş. Ankara: Seçkin.

Kopan, Y. (2018). Aşk Mutfağından Yalnızlık Tarifleri. İstanbul: Can.

Palmer, F. R. (2020). Semantik Yeni Bir Anlambilim Projesi. Ankara: Fol Kitap.

Sert, G. (2019). Anlam alanı ve anlam ezgisi açısından eş anlamlı durum sıfatları: "muhtemel" ve "olası” örneği, Teke, Sayı: 8/1, s. 93.121. doi: http://dx.doi.org/10.7884/teke.4395

Toklu, O. (2015). Dilbilime giriş. Ankara: Akçağ.

Vardar, B. (2002). Açıklamalı Dilbilim Terimleri Sözlüğü. İstanbul: Multilingual.

Yılmaz, H.-Efe, K. (2019). Behçet Necatigil'in 'Kan' Şiirinde Kavram Alanları ve Sözcük Ağları, The Journal of Turkic Language and Literature Surveys, 4 (1), s. 25-50. 